\title{
Nostalgia for enslavement relations in discourses about (but not from) housemaids*
}

\author{
Juliana Cristina Teixeira** \\ Alexandre de Pádua Carrieri*** \\ Eloisio Moulin de Souza****
}

\begin{abstract}
The article analyzes the discourses on domestic workers by Brazilian employers on two online social networks. We have sought to understand from the speeches, what relationships these have with race, gender, and social class categories. The speeches analyzed in this paper strengthen the gender inequalities concerning domestic labor and present classists and racists ideologies that disseminate the inferiority of the Black and the impoverished people while manifesting a nostalgia for enslavement relations.
\end{abstract}

Keywords: Housemaids, Race, Gender, Class, Enslavement.

* Recebido em 12 de fevereiro de 2016, aceito em 19 de fevereiro de 2020. Uma versão preliminar não definitiva deste artigo foi publicada na coletânea de artigos vencedores do Oitavo Prêmio Construindo a Igualdade de Gênero.

** Professora do Departamento de Administração da Universidade Federal do Espírito Santo (DADM/UFES), Vitória, ES, Brasil. julianacteixeira@yahoo.com.br / https://orcid.org/0000-0001-5186-3234

*** Professor da Faculdade de Ciências Econômicas da Universidade Federal de Minas Gerais (FACE/UFMG), Belo Horizonte MG, Brasil. aguiar.paduacarrieri@terra.com.br / https://orcid.org/0000-0001-8552-8717

**** Professor do Departamento de Administração da Universidade Federal do Espírito Santo (DADM/UFES), Vitória, ES, Brasil, eloisiomoulin@gmail.com / https://orcid.org/0000-0002-0775-7757 
O Saudosismo das Relações Escravocratas em Discursos sobre (e não de) Trabalhadoras Domésticas

\section{Resumo}

Este artigo analisa discursos sobre trabalhadoras domésticas publicados em duas redes sociais produzidos por pessoas que se colocam no lugar de contratantes de trabalhadoras domésticas. Buscamos entender as relações dos discursos com as categorias de raça, gênero e classe. Os discursos analisados refletem as desigualdades de gênero relacionadas ao trabalho doméstico, e reproduzem ideologias classistas e racistas que configuram um processo histórico de subalternização de pessoas empobrecidas $e$ negras, manifestando um saudosismo das relações escravocratas.

Palavras-chave: Trabalhadoras domésticas, Raça, Gênero, Classe, Escravização. 


\section{Introduction}

This article aims to analyze the discourse of Brazilian individuals who claim to be employers of domestic workers on two online communities: (1) an Orkut community called Vitimas de empregadas domésticas ("Housemaid victims") and (2) a Twitter account named@aminhaempregada ("@myhousemaid”). Through the analysis, we aim to not only understand the social aspects involving employment relations between mistresses and housemaids but primarily to identify the discursive strategies used for victimization ("Housemaid victims") and their associated ideological aspects of gender, class, and race. Along these lines, it becomes possible to discuss the ideologies disseminated by the speeches posted by the online community members.

We must emphasize that the hiring of domestic workers by the middle and upper social classes is quite common in Brazil. Indeed, it is so common that it has become a widespread practice even among the lower classes, through the so-called "housemaid's housemaids" (Silva; Oliven, 2010). In a study conducted in Morro da Mangueira, in the city of Rio de Janeiro, Silva and Oliven (2010) observed that the sub-housekeepers are mostly underage girls who work with no labor protections, with earnings below the minimum wage and extended working hours.

These workers are hired to perform household chores and work as daily or monthly laborers. The difference between the two categories is that monthly workers work on a daily basis and have certain labor rights. The law provides that monthly workers should work full-time, six days a week, while day laborers should work a maximum of two days a week (although this is not always complied with), with no labor rights or social benefits whatsoever. However, the per-hour rate paid to daily workers is generally higher than monthly workers, therefore, for this and other structural reasons, many housemaids prefer working as day laborers.

We also must emphasize that we use the female words mistresses and maids in this paper for two primary reasons. First, 
because women are more often involved in the discussions held on the online communities (although they also have a few male members). Secondly, they account for $97 \%$ of all domestic workers in Brazil (IBGE, 2020). Furthermore, as we intend to incorporate the gender approach to this analysis, we have chosen to focus on the female gender, which fits the context of social production of the discourses analyzed herein. There is a scenario of gender inequality not only regarding the labor activities that are to be performed by women but particularly regarding the ideologies that maintain housework as an activity designed for them.

Discourse is understood in this paper as a form of social construction, that is, as the non-neutral expressions, ideologically and contextually referred to the positions that individuals occupy in terms of social categories such as gender, class, and race. Besides, they refer to particular historicity and specific social contexts and panoramas. In terms of social contexts, we consider not only the sexual division of labor but also the historical conditions of domestic labor in Brazil. In this regard, we address their ties with the period of slavery as well as the country's current scenario, in which the number of day laborers has grown and the number of employees who want to work as monthly workers has decreased. Likewise, the level of education of the younger laborers has also improved, so they no longer perceive housework necessarily as their only source for subsistence, but in some cases as a temporary activity.

Politically, the decision to study aspects involving domestic labor is equivalent to "talk about an uncomfortable subject, for this is a theme that opens wide social inequality [in Brazil]; the unequal division of household labor and brings to our lives, to our everyday experience and the explanation of capitalism and sexism" (Ferreira, 2010:338), in addition to discussing issues of race and class. Therefore, this paper analyzes gender, race, and class aspects in their relationship with domestic workers, as there is a lack of organizational studies addressing issues involving race and gender (Holvino, 2010). 
To better contextualize the readers on the speeches posted on the aforementioned online communities, we must say that Orkut was the first social network to be widely used in Brazil (Estadão, 2012), and was maintained by Google until late 2014. It featured the second largest number of members in Brazil, at around 34 million users ${ }^{1}$ (Comscore, 2012), and kept the lead from its inception in 2004, until it was eventually surpassed by Facebook in 2011. Twitter is a microblog released in 2006 that operates through short messages up to 140 characters. Brazil is one of the countries that publish most tweets worldwide, and Portuguese is one of the most used languages on this network.

The potential contributions of this research lie in the investigation of the ideologies present in labor relations. Moreover, according to Dunne et al. (2008), race is one of several issues that remains virtually silenced in the field of organizational studies. Therefore, although this article focuses on the domestic sphere, it also delves on aspects linked to ideologies in broader contexts; that is, the ideologies disseminated herein can be identified in other labor spheres as well (such as the dimensions related to gender, class, and race). This study also contributes to labor studies by emphasizing the importance of addressing it along with their sociohistorical and contextual aspects.

The article is organized into sections. The next section presents a theoretical framework discussing discourse as a vehicle for ideologies, sexual and class division of labor, and domestic labor and enslavement in Brazil. This is followed by the methodology, the results (the scenario of domestic labor as a social condition of discourse production and defended and widespread ideological aspects), and the final remarks.

\section{Discourse as a vehicle for ideologies}

The notion of discourse as it is defined in this work opposes the traditional conception of language, that is, a "system of signs,

\footnotetext{
${ }^{1}$ Data provided by ComScore, an organization that carries out global surveys on the digital market. The number of users refers to the research published in January 2012 and represents the number of users of that particular social network in Brazil, in December 2011.
} 
that is, a virtual system of formal and abstract rules that excludes historicity" (Pereira \& Brito, 2009:62). In this paper, this concept runs counter to a common view on language that perceives it as a tool merely used to describe things and inform about reality (Boje, Oswick \& Ford, 2004).

What we seek here is to go beyond discourse as a mere form of language use. Instead, it is replaced by other essential components, such as who uses the language as well as how, why and when (Van Dijk, 1997), providing evidence about the sociohistorical conditions of a given text (Brandão, 2002). In this sense, discourse can be understood as speeches, utterances, and texts within a given context (Van Dijk, 1997). This context may include the positions that subjects hold in the social categories, hence incorporating spatial (or geographic) and historical elements. The historical elements are significant because "it is in the relationship between linguistic and historical aspects that discourses are built" (Faria, 2009). Therefore, such elements are sought for in the analysis conducted herein.

In addition to understanding the context, one begins to seek "an understanding of the phenomenon of language no longer centered exclusively in language as an ideologically neutral system" (Brandão, 2002:10). In this sense, discourse comes as an instance of language in which one can articulate the linguistic phenomena with the associated ideological processes (Van Dijk, 1997). That is, as we think of discourse instead of language, a link between the linguistic and extra-linguistic levels is established.

In Marxist theory, ideology is understood as an ordered system based on ideas or representations connected to a concept of class, as well as an indication and prescription of how to think, what to think, what should be done, and how something should be done (Brandão, 2002). A more generalist perspective perceives ideology as "the imaginary relationship between individuals and their real conditions of existence" (Brandão, 2002:22), through the creation of symbolic forms they relate with the concrete reality. Discourses are embodiments of ideological materiality (Brandão, 
2002) and take place through "a set of themes and figures which comprises a given world view" (Fiorin, 2005:32).

Back to the characterization of discourse as adopted herein, we can say that it also relates to two other concepts: utterance and enunciation. Utterances comprise what is literally said (Godoi, 2005); it is the text itself (Faria, 2009). In turn, enunciation relates to the subject in discourse (Godoi, 2005); it is that which constitutes an utterance (Maingueneau, 2006). According to Faria (2009), enunciation is to utterance what a process is to a product. It is the act of enunciating, or "a unique event, situated in time and space" (Maingueneau, 2006:54). That is, it is unique and cannot be repeated, and, therefore, different enunciations may convey the same utterance (Brandão, 2002).

As we adopt a notion of discourse that emphasizes the significance of the historical context, the next section addresses the sexual and class division of labor and paid domestic work as a legacy of the slavery period in Brazil. Enslavement defined "the quality, the extent, and the intensity of the physical and spiritual relationship of the natives of three continents", referring to Portuguese colonizers, Black African slaves, and Indigenous people all as native Brazilian peoples (do Nascimento, 1978:48).

\section{Sexual and class division of labor}

There is a historic division of labor, which has been socially constructed and linked to the social relations between genders. This division predates the capitalist system of production itself, as it ended up benefiting from it by taking advantage of the sexual division of labor that preceded it, which, in turn, linked women to their reproductive function for the social sphere (Rubin, 1993, Silva \& Blanchette, 2018). This led to a different dynamic, with the late insertion of such women in the formal labor market, compared to men. It is historically characterized by the actions of men both in the public and the productive spheres, as well as women in the private and reproductive spheres.

Indeed, the inclusion of women in the public and productive spheres was accompanied by the keeping of such division and by 
the participation of women in precarious and vulnerable jobs, especially if we consider the beginning of the introduction of women in jobs where they could remain as the persons in charge of domestic labor, such as part-time work. This concerns the fact that the inclusion of women in the labor market was not accompanied by an appropriate sexual division of household chores (Hirata, 2003), and that men had access to educational opportunities beyond those that became stereotyped for women (such as care, pedagogy, and nursing) (Vianna, 2001).

Furthermore, another important aspect concerns discrimination and the perception of women as less capable of performing certain types of labor activities. This is associated with an idealized social construction of the necessary instrumental rationality for the execution of formal work as something inherent to masculinity, which would be, according to certain conservative views, restricted to men (Carrieri, Diniz \& Souza, 2013; Steil, 1997). In short, the inclusion of women in the labor market has not been accompanied by the appropriate sexual division of household chores (Hirata, 2003)

In addition to this contextual scenario of the division of labor between genders, the division of labor among women has also occurred, similarly configuring a polarized scenario in the scope of women's labor. At one end are highly qualified female professionals, and on the other are low-skilled female workers who get low wages and lack social recognition and appreciation. The incorporation of the categories of class and race in this context helps to understand the reasons that have led to such internal division, as the outcomes and insertions in the scope of labor were and have remained distinct, considering historical forms of differentiation in the access to capital and a society that was established through the enslavement of a certain social group. Indeed, most domestic workers in Brazil are Black (Silva \& Blanchette, 2018).

Transformations in domestic work have been slower and to a lesser extent. In fact, these have not followed the complexity of changes in other market sectors in which women have taken part. 
Although some domestic chores are delegated to housemaids, women continue to be responsible for keeping the families' homes. The very hiring of housemaids can be considered a means to alleviate the crises in the relationship between genders within households. Indeed, "while women complement each other carrying out domestic work, the insignificant male involvement in these tasks is guaranteed" (Preuss, 1996:55). For "washing, cooking, caring for the children/the elderly/the ill, listening, empathizing, and being forced to have sex are all forms of work traditionally perceived as domestic and female in the West" (Silva \& Blanchette, 2018:22).

Moreover, the very "division [occurring] among female individuals - between mistresses and maids - [...] contributes to the reduction of the bargaining power of women in the social environment" (Preuss, 1996:55). The same lack of social recognition for paid domestic work occurs with unpaid so domestic work has been and still is historically undervalued. Besides, the existence of paid domestic labor strengthened the internal and hierarchic division between the labor activities performed by the various groups of women. As Luxemburg (1971) points out, women who came to work in the same markets as men have been able to achieve economic independence, which was not necessarily the case with women engaged in domestic labor for lower wages.

Added to that, there has been an increasing commitment by men to their family and children, which has also led to changes in people's relations with their home environment. In this sense, there is a growing number of men sharing chores with women or even taking control of their children's education altogether. However, this change is not hegemonic and has yet to become true for most families and it is common to consider the performance of these tasks by man as mere support or aid. This component expresses a kind of disclaimer on the part of men, as far as those activities are concerned (Wagner, Predebon, Mosmann \& Verza, 2005).

Paid domestic work is an example of the maintenance of the sexual division of labor; it is mainly represented by women who left their homes to work, but only to perform household chores at 
the homes of other women. In this process, the role of women at home is maintained (Coronel, 2010). In that case, what distinguishes the employee from the employer is, among other factors, the socio-economic conditions and the type of activity they are supposed to perform. Housemaids carry out operational activities and general care, whereas their mistresses remain responsible for labor inspection, maintenance, and planning.

Meanwhile, the domestic space, that is, the "home", operates as a boundary in which different races and social classes meet and coexist for a certain period, every day. Many of the women who perform domestic work belong to disadvantaged social classes and are of Black ethnicity, while their mistresses and other family members are usually white and middle or upper-class. This refers to a socio-historical context that has historically fostered the separation between the women socialized to be mistresses and the women socialized to be domestic workers in Brazil, as Kofes wrote in 1982 (Kofes, 1982). Therefore, the household becomes a frontier that Anzaldúa (1987) has called "borderlands". These occur when two or more cultural groups and social classes of different ethnicities occupy the same territory and come into contact and interaction (Anzaldúa, 1987).

Interestingly, even in the scope of domestic work, women are degraded in relation to men, as far as labor rights are concerned. While janitors, for example, have stipulated working hours, all the guarantees contained in the Labor Code, and a salary cap agreed in union conventions, more conventional housework, mainly performed by women, has failed to receive the same legislative treatment (Coronel, 2010). Another example of two groups that do not receive the same legal and social treatment are chefs, who are inserted in a logic of valorization according to approaches of the sociology of professions, regarding the labor practices that derive from opportunities of access to the institutional bases of knowledge; and female cooks, who have cooking as their primary subsistence activity, yet bounded by dynamics that are not recognized as distinguished or even deserving of adequate legal treatment. Such differentiation 
concerns the context of gender inequality reflected in the history of domestic and professional cooking (Collaço, 2008).

Recently, the Brazilian legislation has been amended and now provides for the expansion of labor rights to housemaids. This ensures these workers the legal rights to vacation, overtime, retirement, and social insurance. However, such laws have yet to put an end to stereotypes and prejudice because social structures cannot be simply modified by changing legislation (Galloway, 2011), as discussed next.

\subsection{Domestic labor and enslavement in Brazil}

Domestic work in Brazil ends up mingled with the country's history of enslavement. In the period after the abolition of enslavement (which occurred in 1888), "it was preferable [for former slaves] to support the oppressive manor exploitation in exchange for subsistence and minimum working conditions than face a mischievous society that saw Blacks as a vile anomaly of nature" (Rangel, 2010:34). Therefore, there has been a continued performance of domestic labor. Currently, the context is no longer as described, but historical legacies of that period have remained in Brazilian society. Note that in this paper the concept of race is understood as a social construction that structures, sets, orders, organizes, and manages the social relations (Almeida, 2019; Henry, Tator, Mattis, \& Rees, 2000). However, in a strategy to cover up social relations of domination between groups, the concept of race is often simplified to be considered as a set of purely physical and biological attributes. This reduction process is called "racialization" (Wong, 2010).

In the Brazilian context, as for the relationship between employers and workers that began to be established after the enslavement period (the term came to be used soon after), the fact that these former slaves do not necessarily go on living with the employing family ended up hindering the employers' control over them. This finally brought distrust as a defining characteristic of such a relationship (Roncador, 2007). As for the speeches posted on the online communities, we can observe the maintenance of such 
an ideology, which fosters not only the distrust towards employees, as well as a need to tame them (Freitas, 2014).

Hypothetically, the idealized housemaids would be those that were in the equilibrium zone between proximity and distance from their mistresses (Freitas, 2014). The proximity operates on the need of aligning their values and the distance operates to require employers and employees not to "blend in". Therefore, the characteristics and values of the places where the domestic workers reside may not be present in the relations established in the homes where they work.

In training courses for domestic workers, for example, strategies aimed at correcting habits and used values stand out. These are considered by Oliveira (2007) as modeling strategies. Indeed, what one may call an educational project to encourage the bourgeois fear of servants has been put forward. This project has been reinforced by accounts of violence and physical and moral contagion. Moreover, books targeted at mistress readers foster stereotypes involving maids, including those that affirm that they are invaders of the privacy and intimacy of the bourgeoise families; and the envious and unauthorized consumers of their employers' goods and class habits (Roncador, 2007).

Finally, in addition to the mentioned aspects, which involve issues such as gender and class, it is evident that domestic work is one of the mechanisms of reproduction of a "highly stratified gender, class, and color hierarchical system" (Brites, 2007:91). There are gender constructions that also relate to class and ethnicity constructs, remaining mixed. This context generates a process of naturalization of the subordination of domestic workers (Brites, 2007), which nonetheless is a social construction marked in the everyday life. For instance, in the very domestic environment, there is separation and delimitation of spaces, such as the use of uniforms and service elevators (Azeredo, 2002:333).

In this sense, race is perceived as a historical, ideological, and cultural construction. It operates as an ordering principle, producing not only a social meaning but also ontological truths (Letiche, 2009). The racial and ethnic minorities (Holvino, 2010) 
were created to serve power interests, hence building a racist Brazilian society (Gonzalez, 1984). As Abdias do Nascimento (1978:48) argues, regarding the Brazilian colonial context, "the immediate exploration of the new land began with the simultaneous appearance of the Black race, fertilizing the Brazilian soil with their tears, their blood, their sour and their martyrdom".

Therefore, when we relate gender with race, many Black women do not consider men and their families as the primary social oppressors, but aspects of race instead (Davis, 2011). Lélia Gonzalez studied racism and sexism in Brazil and discussed how Black women who protected Black men were the target of jokes and mockery (Gonzalez, 1984). Nonetheless, Black men continue to face inferior socioeconomic conditions compared to white women in Brazil. For this reason, discussing race, gender, and class involves considering the mutual effects of these oppressions, as Lélia Gonzalez and Kimberlé Crenshaw argue, the second through the concept of intersectionality (Gonzalez, 1984; Crenshaw, 1991). Many "Latin American, African and other [so-called] 'Third World' women have chosen to identify first with liberation and antiimperialistic struggles, joining in solidarity with men against a common oppressor, rather than seeing essentialized men as their oppressor" (Holvino, 2010:254). However, this does not characterize the term "Black women" as an essentialized ontology. In other words, one cannot consider that all "Black women" are identical (Miles \& Torres, 2007; Prasad, 2012).

Finally, strengthening the link between gender and class when discussing domestic labor, the exercise of professional activities by women's middle and upper classes have historically been tied to class issues. This is because this type of activity has depended and still depends, in many cases, on the delegation of tasks to maids, which would be, as a result, reserved for lowerclass women. In fact, "many feminists recognize that the supply and the low wages usually paid to housemaids have allowed women of lower social classes to join the workforce" (Roncador, 2003:57). 


\section{Methodological framework}

The data collection method used in this article was documentary research. First, we conducted a query on Orkut communities with the term "housemaid". 41 communities were found, as shown in Table 1.

Table 1: Communities with the term "housemaid" on Orkut.

\begin{tabular}{|c|c|c|c|}
\hline Communities & $\begin{array}{c}\text { Number } \\
\text { of } \\
\text { members }\end{array}$ & Communities & $\begin{array}{c}\begin{array}{c}\text { Number } \\
\text { of } \\
\text { members }\end{array} \\
\end{array}$ \\
\hline $\begin{array}{c}\text { Vítimas de empregada } \\
\text { doméstica } \\
\text { ("Housemaids' victims") }\end{array}$ & 1485 & $\begin{array}{l}\text { Empregada doméstica } \\
\text { ("Housemaid") }\end{array}$ & 23 \\
\hline $\begin{array}{c}\text { Sou empregada e daí? } \\
\text { ("I'm a housemaid, so what?") }\end{array}$ & 569 & $\begin{array}{c}\text { Não pego + empregada } \\
\text { doméstica } \\
\text { ("I won't get around with a } \\
\text { housemaid again") }\end{array}$ & 15 \\
\hline $\begin{array}{l}\text { Loira é empregada doméstica } \\
\text { ("Blonde and housemaid") }\end{array}$ & 228 & $\begin{array}{c}\text { Eu fui empregada doméstica } \\
\text { ("I've been a housemaid") }\end{array}$ & 21 \\
\hline $\begin{array}{c}\text { Apoio as empregadas } \\
\text { domésticas } \\
\text { ("Support to housemaids") }\end{array}$ & 201 & $\begin{array}{l}\text { Emprego - empregada doméstica } \\
\text { ("Job: housemaid") }\end{array}$ & 13 \\
\hline $\begin{array}{c}\text { Eu amo empregada doméstica } \\
\text { ("I love housemaids") }\end{array}$ & 131 & $\begin{array}{c}\text { Empregada? Doméstica? Nããooo!! } \\
\text { ("Housemaids? No!") }\end{array}$ & 10 \\
\hline $\begin{array}{c}\text { Agência de empregada } \\
\text { doméstica } \\
\text { ("Housemaids Agency") }\end{array}$ & 77 & $\begin{array}{c}\text { Empregadas domésticas BH } \\
\text { ("Housemaids of Belo Horizonte") }\end{array}$ & 9 \\
\hline $\begin{array}{c}\text { Empregada doméstica } \\
\text { ("Housemaid") }\end{array}$ & 77 & $\begin{array}{c}\text { Empregadas domésticas } \\
\text { ("Housemaids") }\end{array}$ & 8 \\
\hline $\begin{array}{c}\text { Eu quero } 1 \text { empregada } \\
\text { doméstica } \\
\text { ("I want a housemaid") }\end{array}$ & 39 & $\begin{array}{l}\text { Empregadas domesticas } \\
\text { ("Housemaids") }\end{array}$ & 7 \\
\hline $\begin{array}{l}\text { Empregada doméstica x patroa } \\
\text { ("Housemaids vs. mistresses") }\end{array}$ & 37 & $\begin{array}{l}\text { Ex empregada doméstica } \\
\text { ("Former housemaid") }\end{array}$ & 11 \\
\hline $\begin{array}{c}\text { Sindicato empregadas } \\
\text { doméstica (s) } \\
\text { ("The Housemaids' Union") }\end{array}$ & 27 & $\begin{array}{l}\text { Empregada doméstica } \\
\text { ("Housemaid") }\end{array}$ & 4 \\
\hline $\begin{array}{c}\text { Empregada doméstica é uó } \\
\text { ("Housemaids suck") }\end{array}$ & 33 & $\begin{array}{l}\text { Outras comunidades } \\
\text { (Other communities) }\end{array}$ & 3 or more \\
\hline
\end{tabular}

Source: Orkut, data updated on June 07, 2012. 
As noted, the community chosen for the analysis of discourses was the one with the largest number of members and was also opened for non-members. Therefore, all forums and discussions could be viewed without membership requirements. The community on the social network was established in November 2004 and was still active in July 2012, when the data was collected. On that occasion, the community had 86 topics of discussion (forums) opened with various themes regarding housemaids and a total of 1,199 comments and responses (posts). In turn, on Twitter, the task of locating the space where the debates on the subject occurred was much easier, since the account represented by the username@aminhaempregada concentrated all posted messages. With such a large corpus, the discourse analysis method was important to identify the most relevant aspects in the discussion, so that it could address the ideological aspects present in the discussions taking place in this mode of virtual community in the data collected later, in 2016. To present the discursive fragments in this work, we opted to change the names of the participants.

We resorted to French discourse analysis to carry out the investigation. To put it into practice, we relied on a script prepared by Saraiva (2009), based on discourse analysis procedures used for teaching purposes by Professor Antônio Augusto Moreira de Faria, for the Faculty of Letters at the Federal University of Minas Gerais, all of which were in accordance with the postulates of French discourse analysis (Saraiva, 2009:90). That script is also based on the ideas of authors such as Maingueneau, Fiorin, and Bakhtin. The analysis steps described in the text are lexical analysis; analysis of themes and figures (explicit or implicit), including the participants; analysis of structured semantic paths; interdiscursive aspects; discursive syntax; reflected and refracted aspects; social conditions of production; discourses present in the text; ideological aspects defended and fought against; and the text position concerning the discourse that is hegemonic in a given society. We emphasize that we did not only select discursive statements characteristic of a given position concerning the hegemonic 
discourse in society, considering the amplitude of the collected positions, which did not consider a distinction of positions. Therefore, there was a uniqueness of positions in the corpus of analysis represented by Orkut.

This script allowed the analysis of aspects such as context, power relations, persuasive strategies, explicit and implicit elements, silences, the said and the unsaid, and the ideological formations present in discourses. Furthermore, since the analyzed speeches are presented as dialogues, there was also an engagement with the relational aspect of discourse (Gergen, Gergen \& Barrett, 2004).

Note that we did not exhaust all the steps of French analysis for every single fragment. Besides, not all the above-mentioned elements will be commented on regarding each one of the analyzed posts. Finally, the transcription of the discursive fragments in the article was done verbatim, to keep them as they were written, preserving the utterances characteristics, such as the use of bold, and upper cases. The English translation of the speeches also followed this procedure.

\section{Discourse analysis}

\subsection{Ideological aspects advocated and disseminated through discourse}

In this section, we present the ideological aspects present in the speeches of mistresses who were members of the surveyed online communities, as well as their relationship with gender, class, and race.

\subsubsection{Dissemination of stereotypes}

Ideologically, we have identified the construction and dissemination of stereotypes involving domestic workers. Some of these are commented on next.

\section{...They are dirty and poor because they want to!}


As Azeredo (2002) points out, the allusion to how housemaids smell and their alleged filth is recurrent and has been confirmed in the speeches found on the online communities. In the following fragment, we see the ideological construction concerning the perception of maids and other low-class individuals. In general, they are perceived not only as filthy but also as accountable for their misery.

[...] Having a maid these days is even ECO-UNFRIENDLY!! Because of the waste thing at your homes and consequently on their own homes AS WELL!!! Yes!!! Since they don't know or wish to save at our houses, they DON'T DO IT AT THEIR OWN HOUSES EITHER!!!! That's why they NEVER LEAVE the ghetto even when they get paid good wages, have you noticed that? even when their mistresses pay well, help them out, give them presents, clothes, etc., they live in complete misery - ALWAYS!!! [...] What about you mistresses? Are you deceived? do you believe THOSE creatures CLEAAAAAAAAAN THEIR HOUSES???????? It's to laugh your ass off!!!!!! Think about it: if THEIR OWN houses are filthy... are they going to clean thy homes??????? think it over! even better: when hiring a maid, PAY HER A SURPRISE VISIT, one day...! you'll THROW UP in disgust!!! and... THAT is the tramp who cleans YOUR HOUSE, ma chèrie!!! KKKKKKKKK (Thaís)

[...] it's been a month since I bought an oven and a cooktop and I can't find a carpenter or an electrician to install them for me! but why? it's the lack of seriousness and professionalism that only Brazilians have. As a matter of fact, it's good to note that most builders, electricians, carpenters are the husbands for... housemaids! Now let's put everything together: a filthy husband, a half-assed job, and being married to a housekeeper ${ }^{2}$, what are the odds of having a "determined and clean worker" at your house? (Luana)

\footnotetext{
${ }^{2}$ Original speech in Portuguese: "agora somemos: marido porco, serviço porco casado com empregadas domesticas".
} 
There you are, inside a bus packed with people and a housekeeper comes next to you with that bleach smell in her hands:::::::: they should go fuck themselves, stinky $\underline{\text { bastards }^{3}}$ (Mariana)

those housekeepers come over to my house and use everything I have, motherfuckers, she's even used my earphones (Camila)

In addition to the points already mentioned, Thaís and Camila resort to a currently hegemonic discourse in society about the need for environmental sustainability to strengthen their opposition to housekeepers. They resignify the fact of having a maid as an anti-ecological practice because housemaids and the impoverished in general are people who tend to waste. This argument also serves as a reinforcement to the meaning that not having a maid would be a more socially adequate and sensible choice.

Referring back to the question of being impoverished as a choice and to the discourse that working is paramount for the dignity of men, one can also identify in the speeches of mistresses the creation of interdiscursivity between work and non-work, between effort and laziness, which opposes, respectively, employers and employees. There are semantic paths established not only to oppose both groups but also to state that they, the mistresses, work, "work hard" and the housemaids (and the impoverished portion of the population in general) do not.

[...] I've suffered countless times with housemaids, I work and have to respect my boss and swallow a bunch of things, but I do it because I respect him and I need the job, but those tramps come in and out of people's houses every day, nowadays I can understand when they tell me they've worked here and there, when the housemaid is good she

\footnotetext{
3 "Você naquele buzão lotado de pé e vem uma empregada do seu lado com mó cheiro de cândida na mão:...........:.: vai se foder sua fedida".
} 
won't step from one house to another, I, for example, have been working at the same place for 29 years and I thank God every day for that... [...] I won't have a maid every day at my house EVER again. I have a cleaning lady every Friday, but I won't become attached to her, I won't pity her, I won't give her anything, I don't want to know anything about her life, if she wants to have something, she can work to get it, just like I do. (Celina)

This is the country of unemployment because... there are JOBS... but there aren't that many workers... (Rafaela)

This interdiscursive strategy between work and non-work ultimately contributes to the mistresses' alignment with the dominant ideology regarding the invisibility of domestic work (Coronel, 2010). Although the ones who suffer the consequences of historical invisibility are women, when mistresses transfer household chores to housemaids, they reproduce the very same dominant ideology. This is because they place themselves on opposite social terms in relation to housemaids since there are other processes of belonging and not belonging involved, such as class and race criteria.

\section{They are criminal offenders!}

Another stereotype says that maids are thieves or criminals. This relates not only to their poverty but also with the social distancing commonly involved in the labor relations between employers and employees. Because of this distance, the mistresses tend to relate the thefts committed by maids to feelings of envy or jealousy on the part of their employees. In terms of social conditions of production, it is important to state that this theft may happen occasionally and when it comes to being a judicial recurrence, they are usually framed by law as crimes against property and theft aggravated by embezzlement (Bastos, 2009).

However, what concerns us about the women's speeches posted on the online communities is the refraction that makes this 
behavior, generalizing all housemaids. These discursive fragments have no ideological neutrality and create not only an image for a whole category of workers but also aligns hegemonic discourses in society. These tend to attribute marginality (in the criminal aspect of that term) to the impoverished, spreading a view that they should be feared by "society".

[...] what if I was a thief? It would be the easiest thing in the world to rob a rich person's house! All I'd have to do was to pretend I was interested in the housemaid! They'd "snitch" on us just fine! $!^{4}$ have you noticed that EVERY BURGLED HOUSE HAS HOUSEMAIDS?? Would that be a "mere coincidence"? hum hum hum Having maids have been and still is? ALWAYS a risk factor for the safety of your family! What about observing them while they're sweeping the sidewalks? They leave the entrance gate wide open and go sweeping waaaaay far from the gate. Have you noticed that in most invasions, the burglar "surrendered the housemaid"? when SHE was taking the garbage out! when SHE was sweeping the sidewalk outside! when SHE was arriving! when SHE was going out! [...] for a simple reason: YOUR house IS NOOOOOOOOOOOT HEEEEEEEEER HOUSE! They talk TOO MUCH! $!^{5}[\ldots]$ and sometimes THEY ARE THEMSELVES the MASTERMINDS of the burglary, all right? Why? because they are HUMAN BEINGS, and most HUMANS are ENVIOUS! At our house, they take care of things they'll NEVER HAVE! And that, by itself, is a reason for them to be jealous! (Bete)

stealing things is what they do best but when it comes to clean the house, they do a half-assed job. they are hustlers, they'll put everything in their purses, from toilet paper to jewelry, don't be silly thinking that your housekeeper doesn't steal. they all steal. the difference is that some steal more often, some steal once a week, whereas others [steal] every day. [...] now go to their houses where everything is

\footnotetext{
4 "Elas me dariam o "serviço" da casa direitinho!"

5 "Elas têm a LINGUA COMPRIDA!"
} 
clean and tidy, and you'll find the things she stole from you. $\mathrm{Oh}$, and take advantage of the opportunity and bring the police along to bust the thief (Felipa)

in the future, I'll be my own housekeeper because for Christ's sake I've never seen a more opportunistic, exploiting, and dishonest race of creatures ${ }^{6}$ (Joana)

Oddly, these are the first speeches in which housemaids are referred to as well-qualified for some practice, that is, something they can "finally" do well: stealing or getting involved in burglary against their employers ("would snitch on them just fine; "STEALING THINGS IS WHAT THEY DO BEST"). Analyzing the two speeches in more detail, we can find and phrases structured towards the creation, in terms of semantic path, a universal identity for the maids - the thief identity - which is observed in the word choices in "EVERY BURGLED HOUSE HAS HOUSEMAIDS", "now and before", "ALWAYS", "risk", "THEY ALL STEAL", among others.

The vocabulary is structured to universalize this identity, but also to persuade. Writing in capital letters and highlighting words is part of that strategy of persuasion. Another strategy used in Beth's speech is the repetition of the pronoun "SHE", which is spelled with capital letters to indicate the presence of the housemaid in all theft incidents. As they attempt to create collective senses exerts considerable influence on community members, we did not observe, for example, answers contesting the refraction and generalization of crime as a practice in which all housekeepers engage. This, in turn, ultimately strengthens the ideological aspect present in these stereotypes.

6 "pilantra". 


\subsubsection{The ideologically classist discourse: The spatial, moral and cultural delimitation between the impoverished and the rich}

This item is presented to situate the comments posted on the communities as speeches having explicitly and implicitly classist undertones. Such discourses present a vision of impoverished individuals as the others, or inferior to the rich. There is also ideological dissemination regarding the need for spatial boundaries between the rich and the impoveriched, primarily from speeches that construct what is supposedly the moral code and culture of the lower classes. That is, the speeches posted on the communities do not relate merely with a category of workers, but also class aspects, which are sometimes racist and sexist as well.

\section{... So, what are the poor really like?}

In this subsection, we intend to clarify that the stereotypes present in the online communities reflect not only the mistresses' perception of housemaids but of the impoverished in general, hence creating, according to the expressions they use, identities of "class"

and "race". These discourses define the identity of the impoveriched people as individuals who like to talk about their hard lives; or who lack intelligence, culture, and willingness to work; or who always covet what the rich possess or consume.

The act of talking about how harsh life is attributed to housemaids and this practice is rejected by the mistresses.

[...] they're EXPERTS ${ }^{7}$ in telling sad stories but take my work on this: out of $\underline{100}$ stories they tell us??? $\underline{1 / 2}$ have happened to somebody they know and ZEROOOOOO to themselves, OK??? So, don't make a fool of yourself!!! Do you know what I'd do when they tried to tell me their "sad life stories"??? I'd place a clock next to us and say: you can tell me now your story: I'll

7 "PERITAS". 
time the minute when it began and the minutes when it ended, and later, at the end of the day, YOU'LL MAKE UP for the time wasted with your story, all right?? when I did this right away with the new ones, they NEVER tried to tell me anything again!!! (Sônia)

Sônia reveals her strategy against the mentioned practice. By threatening to require that her housemaid compensates for the "time" wasted" with her oral accounts, she not only uses the time factor to inhibit her employers but also implicitly presents a discourse of social distance and boundary that would be important, for example, for situations in which newcomer housemaids are being hired (and therefore should be tamed). Through repelling the housekeepers' personal stories, the mistresses can remain distant from what goes on in their servants' lives.

References to the maids' lack of intelligence were also recurrent and were accompanied by reports about the lack of ability to deal with whatever objects the mistresses have. These references silence the very distancing between housemaids and mistresses regarding the access to certain goods and services. By rendering them silent, one ceases to recognize that housekeepers may experience some degree of unfamiliarity as for what they see at their mistress' homes, which is not necessarily related to a lack of intelligence.

For instance, in the following utterance by Rafaela, she builds interdiscursivity while comparing the supposed speech of the "poor" (quite conversational and containing several grammatical errors) to the speech of the rich, which is allegedly more accurate.

One time... I was interviewing a "candidate" and she began saying that: "You see... I can work till 2 or 3 pm, cause I gotta leave early ${ }^{8} .$. Then I replied:

8 "Ói... eu fico no trrabaio até umas 2, 3 horas da tardi... pq, preciso sair cedo" (She writes with grammatical errors indicating the candidate's wrong speech). 
"Sorry.... although you've said that you need to work, the vacancy won't be yours... I want someone that can stay over 8 hours a day, that is, someone who leaves at $5 \mathrm{pm} .$. Then she said: Why does it have to be at 5 pm...? I answered: Because I have to pay you Christmas bonus salary, vacations, a deposit, paid rest period, salaries, social security installments..., give you food and coffee. Why don't you clean my house for free? She stared at me with that disappointed look, then I added... not even if you are a 'Doctor', or pass a civil servant selection process, you'll find a job like that... Live well. (Rafaela)

The structuring of the vocabulary in different ways to reproduce the two speeches socially contextualizes both, while culturally marking them as well. This refers to the prejudice that Lélia Gonzalez discussed regarding the way Black Brazilians speak, which is understood as wrong and inaccurate as it reproduces African language influences in the Portuguese learned from those who colonized Brazil. Besides, this construction involves domestic workers because of the historical connection between domestic work and slave labor, as mentioned above.

The risk of adopting this strategy is precisely its ideological character, which ends up creating two pretentiously universal models to characterize the speeches of two social categories. This renders any possible exceptions to these models silent, although the spoken language is significantly marked by racial categories, as Roth-Gordon (2017) found in a study about the everyday language of slum dwellers in the city of Rio de Janeiro and the language used by the middle classes.

Tanessa - a high school teacher who has a plan to write a book about the household "jewels", also following the notion regarding the supposed lack of culture of the "poor" - claims to have developed some "theories" on housemaids, which even receive 
the support of other members and are present in other dialogues as well.

I've suffered so much in the hands of those wretches that I've developed a few theories on the subject.

1- Brazilian assistentialism ruined the poor people's dignity. Now they want to live off bolsa familia $^{10}$ and the like. Nobody wants to work. This, associated with impunity is what takes everyone to try to take advantage of things while screwing the others.

2- DNA - I believe their DNA brings up memories of slavery times. they love mistresses who discriminate against them, pay peanuts, force them to work hard, and disrespect their citizen rights by not signing their employment record card.

I live in the countryside and I've seen characters who worked for 10 years or more at a house without being formally employed and being paid half of the minimum wage. I don't get it!!!!!! How is this possible? Mistresses who make them eat housekeeper food, long working hours, etc. and yet they stay there for $\underline{10}$ yeaaaaaaaaars!!!!!!!!!!!!!! We pay them everything and they won't stay! I really want to write a book on that. (Tanessa)

People would rather lead a bad life than to do things right and live better... (Letícia)

The one who was supposed to come didn't show up! She said it was far away from his house! Does she really need to work? Holy God! The cool thing is to have children and get by on the government's benefits. A legion of lazy people,

${ }^{10}$ Bolsa Família is a cash transfer program implemented in Brazil during President Lula's administration, targeted at Brazilian families living in poverty and extreme poverty. 
that's what that government is creating! and as it seems, they've managed to buy these elections too! Dilma is running ahead, can you believe? (Laura)

Reinforcing what was previously mentioned, the impoverished are supposedly responsible for their misery ("people would rather lead a bad life"). Tanessa and other mistresses link the discourse stating that the impoverished do not like to work ("nobody wants to work properly, they lack the will, do they really need to work?'). This appears not only as a form of criticism against the welfare and assistance programs implemented during the terms of presidents Lula and Dilma but also as a position that reveals an opposition of these women towards the Workers' Party ("Partido dos Trabalhadores, PT").

For instance, in one of the fragments, a young man calls a housemaid stupid for having washed his clothes incorrectly while associating such stupidity to the fact that "she has even voted for Lula!". The lexical choices in this excerpt ("even") semantically constructs - from the voting topic and from the character of Lula the idea that such a choice is a moronic attitude that adds to her overall foolishness.

The discourse of scientism is also emphasized in Tanessa's statement. As the speaker enunciates from the place of someone who plans to write a book on housemaids, she uses science as an argumentative and persuasive effort, claiming to have developed some theories on the subject. Furthermore, she arranges her sentence by resorting to the metaphor of DNA, which also concerns science, to naturalize the behavior of housekeepers, causally relating their identities to enslavement. Such a metaphor holds the idea that "memories of slavery times" could be present in the housemaids' genetic code.

Tanessa also resignifies labor relations between maids and mistresses when she says that "they love employers who discriminate them", creating interdiscursivity between these mistresses that discriminate and themselves, who are in the 
community and would be, instead, good mistresses ("we pay everything and we sign their employment record cards").

Another identity characteristic attributed to the impoveriched people is the fact that they always wish (or should wish) what the rich possess or consume because those goods and services are supposedly superior.

I had just got married and I didn't work yet. I had a housekeeper and at that time I was cooking some steaks, then asked her how she liked them, rare or well done. She replied: I set the table and at that time we'd sit together to have lunch. (my husband was working). It was a loin steak, two inches thick, juicy, delicious. She ate everything, but not the steak. Then I asked her why and she said she didn't eat steak unless it had onions. Man, that pissed me off. She didn't even have what to eat at home. She must have never seen a steak like that!!!!!!!! A real Argentinean chorizo!!!!!!!!!!! I'll be damned!!!!!!!!! (Lúcia).

When considering that the maid should have eaten the steak because it was of good quality, and she might not "even have what to eat at home", Lucy denies her employee (and implicitly all the impoverished by extension) the right to choose and have personal preferences that operate as independent criteria to establish the boundaries between "poor people food" and "rich people food". The idea that the impoverished, by being in need, cannot choose what to eat, is spread implicitly and ideologically. Regarding Black people specifically, Neusa Santos Souza even discussed what she called the Black myth (Souza, 1983). She discusses both the idealization that white people built concerning Black people, as well as a structural process that wants Black people to take as a model of social ascension the one stipulated by the white standards.

Another aspect attributed to the impoverished and not only to housemaids, as already mentioned, is filth, which is something that mistress must keep away from their (implicitly tainted) families. 
The other day I was putting the bedsheets away, in the bedroom she had been staying in and that had been ironed before she arrived, and I smelled something funny... I HAD TO WASH IT ALL OVER AGAIN AND SOAK INTO A BUCKET FOR THE STENCH TO FADE. It was rotten! It smelled like rotten flesh! To this date, I still haven't figured out how she did that! For the love of God! And we must pay for that! (Alice)

My cousin who also struggles with them has taught me two things before hiring anyone. First, check their hands and feet. If her feet are dirty, dismiss her. Secondly, when she gets into the restroom, stay behind the door. If she doesn't wash her hands, dismiss the hog, because she'll cook your food with her dirty hands after wiping her ass!!!!!!! Rsrsrsrs This sounds crazy, but it works You can hear the water flowing from the outside. You don't need to drill a little hole in the door!!!!! Rsrsrsrs ${ }^{11}$ (Bete)

Bete's speech reveals a practice that refers to the period of enslavement when the enslaved were chosen through a variety of bodily criteria. As elements related to the social conditions of production of these discourses that stereotype the impoverished, there are practices in Brazilian society ranging from "sexism to racism, class prejudice to sexual prejudice, naturalizing exclusion and inequity, and the hiding of social divisions and injustice under the imaginary unity of "verdeamarelismo ${ }^{12}$ " (Chaui, 2003:11; Coronel, 2010:8). In this context, we identify another element that ends up characterizing the presence of class-discourse within the community: the sharing of ideologies that claim the division (including the spatial) between the rich and the poor.

\footnotetext{
${ }^{11}$ Brazilian Internet slang for "laughing out loud".

${ }^{12}$ Nationalist literary movement that rejected European interference.
} 


\section{... The segregation between the impoverished and the rich}

Given the constructed imaginary of impoverished individuals, the rich would be left with the need to delimit boundaries that isolate themselves. However, as this demarcation may be threatened when you hire a maid that brings elements of their place of origin or residence, some discourses indicate the existence of mechanisms to ensure the continuity of such demarcation, even within the same domestic environment.

Last week I went to see my doctor and we talked about housemaids. He told me he'd bought an apartment that had a maid's room and he had it turned into a pantry. His aunt yelled at him, saying she would use his. He replied: "Aunt, my wife and I are out all day long. Do you think she won't use my bedroom when she's all by herself? Of course, she will, so why am I going to waste room to keep a bathroom as an ornament... Totally right. They use ours indeed!!! All you have to do is to check the toilet paper consumption!! And to make things worse, if she can't throw the toilet in a wastebasket, they'll flush it down so as not to leave tracks. (Vera)

This statement reveals not only the spatial boundary between employees and employers but also the lack of confidence in the mechanisms used for such delimitation. If the housemaid is not trustworthy, it would be pointless, for instance, to have the "maid's room", since it would be unfeasible to watch her all the time. This discussion is contextually related to something that is happening in the new habitations: the reduction or termination of rooms designed for maids (Harris, 2007).

mine ditched work for TWO DAYS IN A ROW... she knew that my mother had had a stroke, she was recovering and couldn't stay by herself, (so I had to cancel my appointments to stay with my mother and almost lost two clients) - and you know why??? Because my housemaid's motherfucking son who is EIGHT years old has 
PSYCHOLOGICAL problems... What is he thinking? A poor child with psychological problems??? I'm going to kick that bitch out as soon as I find a new one... NOBODY deserves a housemaid like that...

Those demarcations indicate that lower-class people cannot afford to have mental problems because they do not have the right to do so. There is interdiscursivity between the health problems of the mistress' family, the health problems in the housekeeper's family, and the ways of dealing with them. In the case of the mistress' family, her "mother" who had a "stroke" "couldn't stay by herself". In the case of the housemaid's family, it is the "eightyear-old" boy who is facing "PSYCHOLOGICAL problems" he is not supposed to have, for "poor children [shouldn't have] psychological problems". Implicitly, it is claimed that mental disorders are a luxury restricted to the rich only. Furthermore, it communicates the idea that the way to deal with the problem would be also different. For the housekeeper ("bitch"), differently from the mistress who canceled appointments to stay with her mother, cannot miss a day of work to stay with her son. Again, this demonstrates the desire for the devoted housemaid, fully dedicated to the needs of their employers.

The boundaries between the rich and the poor in the speeches on housemaids show us how "the legacy of slavery left deep marks and imposed severe divisions in Brazilian society" (Silva, 1998:26). Brites (2007) calls this process "didactics of social distance", which feeds off the very affective ambiguity present in the relationship between employers (especially women and children) and housekeepers.

It is important to contextualize these discourses as being built by some women who grew up getting the influence of hierarchical environments and routines. Children seem to be less distant from housekeepers as compared to mistresses (a closeness that is feared by many of them), for they "talk to [...], hear their stories, listen to the same music [...] ask many things" (Brites, 2007:99). However, as they grow up, they eventually end up contributing to the 
maintenance of this unequal relationship. As Brites (2007) points out, they are socialized in a deeply hierarchical logic that ends up stranding housekeepers in a world apart.

This social distancing process can influence not only the way relationships are established at home, but in other areas beyond domesticity. Therefore, what is discussed here does not only regard the relationships that remain in the private sphere but the relationships that are embedded in the various social spheres.

\subsubsection{In the end, we find what was at the beginning of history: slavery}

In the speeches posted on the online communities, there is an explicit strategy of reversal of the enslavement relationship, in which mistresses place themselves as enslaved to their housemaids. However, we consider this inversion only apparent as there are an implicit claim and even a sort of nostalgia concerning the labor relations of that period.

Regarding the social conditions of discourse production in this work, we can contextualize the implicit desire for the restoration of slavery relations, not only as something reminiscent of the enslavement period but also of post-slavery as well, when labor relations and forms of control had to be reconstructed (Roncador, 2007).

Besides, that feeling of nostalgia has established a sort of class struggle, as employees are no longer the property of others, nor they must faithfully fulfill all the obligations put forth by their employers. In other words, they are no longer the employees their employers expect them to be. Officially, there is no enslavement regime which employers can resort to, so they end up developing everyday strategies to keep vestiges of enslavement within the relationships they establish with their employees. In this sense, when they show their desire to have the "housemaids of soap operas", that is, devoted to their bosses, they end up implicitly claiming for formerly enslaved servants. 
However, the mistresses who are members of the online community find themselves in a context in which new particularities emerging for domestic workers end up driving the former enslavement relationships even further away. The growth in the number of day laborers brings new configurations for labor relations. One example is the question posted by Priscilla, who was confused by the day laborer's claim that she would be hired only for specific services.

my housekeeper told me that washing is not her task, in other words, a day laborer does not wash clothes or cook, is that true? (Priscila)

[...] if you hired for something specific, the person will only make the agreed, if you hired them for the general chores, it would be for all. They now think that cooking and ironing is a specialized service, you must notify before. Those young ladies, they're so full of it... (Elisa)

These fragments reveal a context of adaptation for these new professionals. This new context is reframed by mistresses as, once again, a refusal of employees to perform the work that it is up to them ("those young ladies, they're so full of it').

In addition, it is interesting how some enslaved topics remain in the working relationship developed between mistresses and maids: the "shelf life ${ }^{13}$ " of these women, for example, is always emphasized, an aspect that was also considered during the purchase of enslaved people.

finally a moment of calm. I've had a housekeeper for nearly a year now, and I like her. she's never missed a day, she doesn't steal, she is careful, cooks very well. really, sometimes I pinch myself, I think I am dreaming. may god keep it like that. There's something I've learned. maids have a shelf life and I hope this new one will last longer. (Luana)

13 "Prazo de validade". 
The day laborer who is with me now, Maria, is one of these rarities we can hardly find these days. [...] But her daughter will have twins and is only 17, so she will have to assist in the early days, and on the other hand poor me here, I will have to travel for health treatment in September, leaving my daughters alone at home for ten days. So, I'm trying to hire another person, but only temporarily, because I know that lightning never strikes twice in the same place. I would be very lucky to find another one like Maria (Natália).

One can also find ambiguity in the relationship between mistresses and maids. While there may be personal relationships that reflect how close they live and of the sharing of domestic responsibilities, a slave inheritance, and social distance also remain regarding labor relations (Brites, 2007). In addition, we observed that the sexual division between men and women is also implied in the speech by Natalia, as there is invisibility concerning the sharing of domestic responsibilities and the children between mothers and fathers. Her daughters need to stay home alone due to their mother's trip.

Finally, we can assign to some of the speeches a kind of suppressed rage, a kind of desire to do justice to the freeing of enslaved people or their ancestors:

trust me on this. the rule is... you have to enslave them and be very bad... I do it and do not regret it... I like to catch them in the countryside to live in slave quarters (that is in my house rsss) ... when they start to act like a smart ass, I rule them out... I never suffered again... for me, they can go on working $14-16$ hours a day... (Anonymous)

now one of my consumer dreams is to hire a woman to be my maid and so I can call her an "ape" (Beatrice)

The maid wakes me with scandal, I'm going to slap that old ape face, is she jealous I can sleep all day? (Jocarla) 
Therefore, we observe contextually understandable speeches considering the remnants of a phenomenon that was the very beginning of this whole trajectory: the Brazilian slavery period. Jocarla and Beatrice consider their housemaids "apes", making explicit that all maids are supposedly Black and therefore belonging to an inferior species. In Brazil, this lexical item assumes specifically racial connotations because of the rather significant incorporation, in this context, of evolutionist racial theses which considered Blacks as biologically inferior, according to a social Darwinism perspective. As a matter of fact, in comparison with another expression that did not stem from this social context of discursive production, we could affirm, according to the suggestions of reviewers of this paper, that the sense attributed to "apes" in the country would be similar to that of "nigger" in other contexts. The relationship between race, enslavement, and housemaids can be also seen in Figure 1.

Figure 1: The group's thumbnail on Twitter.

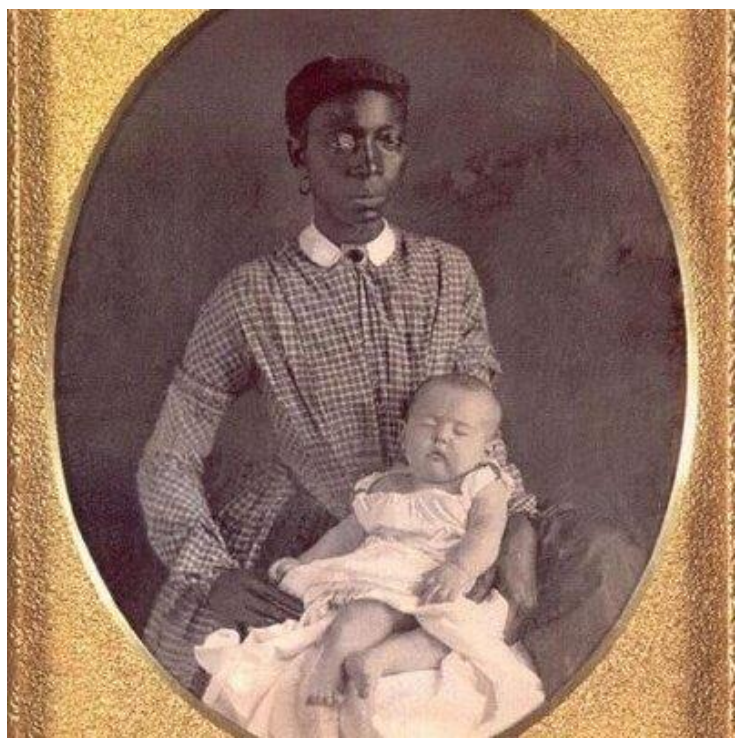

Source: Twitter, data updated on January 07, 2016. 
An image containing the phrase "Don't let the whip hit you on the way ouf' (Orkut, 2012) is the main community on the Twitter icon. This refers to the time of enslavement in Brazil and shows a Black enslaved taking care of a white baby. The scene reinforces the idea that the domestic space caregivers should be Black, and it shows in the seriousness of their facial expressions their total submission to the white master. This reinforces the idea that Blacks and whites are not only in different social positions but that Blacks are treated like animals (apes) that, just like other animals, should be exploited by the whites to perform manual labor.

To conclude the discussion of the results and pointing at some of the limitations of this study, we suggest that the Brazilian debate on whiteness be incorporated into these discussions, as the analysis starts from the perspective of the discourses produced hegemonically from this structural place of oppression (Bento, 2002; Cardoso, 2011; Gouvêa, 2016; Guerreiro Ramos, 1957; Silva, Oliveira, Gouvêa \& Souza, 2020).

\section{Final remarks}

This paper aimed to analyze the speeches of mistresses on domestic workers posted in communities on the social networks Orkut and Twitter. With lexical choices referring to enslavement in the various speeches analyzed, it is inevitable to end the discussion addressing this topic. The analysis results point to an inversion strategy regarding the enslavement relationship, and these are connected to the main speeches within the community. These speeches refer to the characters of the victim mistress and the wicked housemaid.

The speeches are inserted in a context of significant changes in the scope of Brazilian domestic labor, in which part of the maids has been migrating to more autonomous labor relations, moving away even further from the ideal maid profile. Similarly, this profile is ideologically constructed by mistresses in the community and 
respects the characteristics of the servants in the enslavement period.

In this sense, there is a nostalgic discourse regarding slavery labor relations. The legacies of that period have persisted not only in the established labor relations but also in the discourses and ideologies posted on the social networks. As stressed by Rangel (2010:41), "slavery is not a sad fact buried in the distant imperial past. Its stigmatizing brand still echoes in the present". For instance, what can one say about the social and legal segregation that falls upon domestic workers?

The results also reinforce the maintenance of the sexual division of labor in our society. Explicitly or implicitly, women still regret not being at home taking care of the household and their family. This self-inflicted demand leads to irritation against maids themselves, who carry out work that was supposed to be their own. However, there is an explicit questioning about sexual division, since women prove not to claim greater collaboration or compromise from men as for household chores. Therefore, there are ideologies in these speeches that end up contributing to the maintenance of such a division.

Another significant result of the analysis, to which we attribute paramount importance, is the presence of classideological discourses that advocate and disseminate the degradation of the impoverished as compared to the rich, as well as the existence of boundaries and inequalities between them. The speeches by the mistresses suit a context of a social hierarchy consisting of aspects such as race, color, ethnicity, social class, and religion. In this sense, these discourses can be considered aligned with the hegemonic discourses in our society.

Furthermore, the ideological discourses related to class are explicit, although gender and race cut-outs are not always such. Elements such as skin color and ethnicity are silenced or even implicit. This silencing or concealment is understandable if we consider that in Brazil there is the mythical discourse of racial democracy (Galleon-Silva \& Alves, 2004), a form of cultural speech diversity, and an attempt to adhere to what is politically correct. In 
this sense, they exceed some barriers of political correctness, but also resort to it, when they leave the issues of color and ethnicity unsaid.

This study contributes to the labor relations studies because it reveals class, gender, race, and religion demarcations that may be present in various spheres that go beyond domestic work. The attitude of mistresses towards their maids, along with speeches that bring about such boundaries may reflect what happens in our society, because these same mistresses are embedded in other social relations as well.

The discourse perspective and the method of analysis employed contribute to demonstrate the relevance of studying the speeches as forms of social construction and expression and dissemination of ideologies.

Finally, we suggest that future studies employ a more dialogical analysis of the speeches, incorporating aspects of the relationships between mistresses and maids, thus allowing the speeches by the maids to emerge as well. Although the focus of this research has privileged the online social communities about domestic workers who had the most members compared to a fairly small number of maids in other communities, it is still an effort that deserves to be made.

\section{References}

ALMEIDA, S. de. Racismo Estrutural. São Paulo: Pólen Produção Editorial LTDA, 2019.

ANZALDÚA, G. Borderlands/La frontera: the new mestiza. San Francisco, Aunt Lute Books, 1987.

AZEREDO, S. A ânsia, o sino e a transversalidade na relação entre empregadas e patroas. cadernos pagu (19), 2002, pp.323-334. DOI: 10.1590/S0104-8333200200014

BASTOS, J. J. C. Furto qualificado: interpretação e crítica. Revista da Esmesc 16(22), 2009, pp.153-183. Retrieved January 28, 2016, from https://jus.com.br/artigos/12743/furto-qualificado- 
interpretacao-e-

critica\#: : :text=furto\%20qualificado!, \%E2\%88\%92\%20bem $\%$ 20mais\%20elevado\%2C\%20portanto.

BENTO M. A. Pactos narcísicos no racismo: Branquitude e poder nas organizações empresariais e no poder público. Tese de doutorado, Psicologia, USP, 2002. DOI: 10.11606/T.47.2019.tde-18062019-181514

BOJE, D. M.; OSWICK, C.; FORD, J. D. Language and organization: the doing of discourse. Academy of Management Review, 29(4), 2004, pp.571-577. DOI: 10.5465/amr.2004.14497609

BRANDÃO, H. H. N. Introdução (Introduction). In: Brandão, H. H. N. (org.). Introdução à análise do discurso. 8. ed. Campinas, UNICAMP, 2002, pp. 9-12.

BRITES, J. Afeto e desigualdade: gênero, geração e classe entre empregadas domésticas e seus empregadores. cadernos pagu (29), jul./dez. 2007, pp.91-109. DOI: 10.1590/S010483332007000200005

CARDOSO, L. O branco-objeto: O movimento negro situando a branquitude. Instrumento: Revista de Estudo e Pesquisa em Educação, 13(1), 2011. Retrieved November 13, 2020, from https://periodicos.ufjf.br/index.php/revistainstrumento/article/vie w/18706

CARRIERI, A. D. P.; DINIZ, A. P. R.; SOUZA, E. M. D; MENEZES, R. S. S. Gender and work: representations of femininities and masculinities in the view of women Brazilian executives. BAR-Brazilian Administration Review 10(3), 2013, pp.281-303. DOI: 10.1590/S1807-76922013005000002

CHAUI, M. A. A filosofia como vocação para liberdade. Revista Estudos Avançados da Universidade de São Paulo (USP), 17(49), 2003. DOI: 10.1590/S0103-40142003000300002 
COLLAÇO, J. H. L. (2008). Cozinha doméstica e cozinha profissional: do discurso às práticas. Caderno Espaço Feminino, 19(1). Retrieved January 28, 2016, from http://www.seer.ufu.br/index.php/neguem/article/view/2107

CORONEL, M. C. F. G. "Mulheres domésticas": profissionais de segunda classe. Revista de Direito, 13(17), 2010, pp.7-18. Retrieved January 28, from https://revista.pgsskroton.com/index.php/rdire/article/view/1892

CRENSHAW, K. Mapping the margins: intersectionality, identity politics, and violence against women of color. Stanford Law Review, 43(6), 1991, pp.1241-1299. DOI: 10.2307/1229039

DAVIS, A. Y. Women, race, \& class. Vintage, 2011.

DO NASCIMENTO, A. O genocídio do negro brasileiro: processo de um racismo mascarado. Paz e Terra, 1978.

DUNNE, S.; Harney, S.; Parker, M. Speaking out: The responsabilities of management intellectuals: a survey. Organization 15(2), 2008, pp.271-282. DOI: $10.1177 / 1350508407087871$

FARIA, A. A. M. Aspectos de um discurso empresarial. In: CARRIERI, A. P.; SARAIVA, L. A. S.; PIMENTEL, T. D.; SOUZA-RICARDO, P. A. G. (org.). Análise do discurso em estudos organizacionais. Curitiba, Juruá, 2009, pp.45-52.

FERREIRA, J. S. Trabalho em domicilio: quotidiano de trabalhadoras domésticas e patroas. Caderno Espaço Feminino, 23(1/2), 2010, pp.339-360. Retrieved January 28, from

http://www.seer.ufu.br/index.php/neguem/article/view/12239

FIORIN, J. L. Linguagem e ideologia. São Paulo, Ática, 2005.

FREITAS, J. B. Sobre a humilhação no cotidiano do emprego doméstico. Dados - Revista de Ciências Sociais 57(1), 2014, pp.199-236. DOI: 0.1590/S0011-52582014000100007. 
GALEÃO-SILVA, L. G.; ALVES, M. A. A crítica do conceito de diversidade nas organizações. Revista de Administração de Empresas 44(3), 2004, pp.20-29. DOI: 10.1590/s001152582014000100007

GALLOWAY, L. The experiences of male gay business owners in the UK. International Small Business Journal 30(8), 2011, pp.890-906. DOI: 10.1177/0266242610391324

GERGEN, K. J.; GERGEN, M.; BARRETT, F. J. Dialogue: life and death of the organization. In: GRANT, D. (ed.). The Sage handbook of organizational discourse. London, SAGE, 2004, pp.79-104. DOI: 10.4135/9781848608122.n2

GODOI, C. K. Análise do discurso na perspectiva da interpretação social dos discursos: uma possibilidade aberta aos estudos organizacionais. GESTÃO. Org-Revista Eletrônica de Gestão Organizacional3(2), 2005. Retrieved Janeiro 28, 2016, from https://periodicos.ufpe.br/revistas/gestaoorg/article/view/21574

GONZALEZ, L. Racismo e sexismo na cultura brasileira. Revista Ciências Sociais Hoje 2(1), 1984, pp..223-244. Retrieved January 28, 2016, from https://www.jstor.org/stable/pdf/j.ctvnp0k3f.28.pdf

GOOGLE impulsionou liderança do Facebook no Brasil. Blog do Estadão. Retrieved July 7, 2012, from http://blogs.estadao.com.br/link/tag/orkut

GOUVÊA, J. B. Pensando as relações raciais no mundo do trabalho: um olhar a partir da branquitude. In: Congresso Brasileiro de Estudos Organizacionais, 4., 2016, Porto Alegre. Anais... Porto Alegre: SBEO, 2016, p. 1-8.

GUERREIRO RAMOS, A. Introdução crítica à sociologia brasileira. Rio de Janeiro: Editora UFRJ, 1957.

HARRIS, D. E. 'Você vai me servir': desigualdade, proximidade e agência nos dois lados do Equador (Doctoral dissertation, Universidade de São Paulo), 2007. 
HENRY, F.; TATOR, C.; MATTIS, W.; REES, T. The colour of democracy: racism in canadian society. Toronto, Harcourt Brace, 2000.

HIRATA, H. Tecnologia, formação profissional e relações de gênero no trabalho. Revista Educação \& Tecnologia (6), 2003. Retrieved January 28, 2016, from http://revistas.utfpr.edu.br/pb/index.php/revedutecct/article/view/1081/684

HIRATA, H.; KERGOAT, D. Novas configurações da divisão sexual do trabalho. Cadernos de Pesquisa 37(132), 2007, pp.595-609. Retrieved January 28, 2016, from https://www.scielo.br/pdf/cp/v37n132/a0537132.pdf

HOLVINO, E. Intersections: The Simultaneity of Race, Gender and Class in Organization Studies. Gender, Work and Organization 17(3), 2010, pp.248-277. DOI: 10.1111/j.14680432.2008.00400.x

INSTITUTO BRASILEIRO DE GEOGRAFIA E ESTATÍSTICA IBGE. CENSO 2010: características da população e dos domicilios: resultado do universo. 2011. Retrieved January 28, 2016, from http://www.censo2010.ibge.gov.br/resultados_do_censo2010.p hp

INSTITUTO BRASILEIRO DE GEOGRAFIA E ESTATÍSTICA IBGE. Pesquisa nacional por amostra de domicilios: síntese de indicadores 2019. Rio de Janeiro: IBGE, 2020. Retrieved November 13, 2020, from https://www.ibge.gov.br/estatisticas/sociais/protecaosocial/9221-sintese-de-indicadoressociais. $h$ tml edicao $=25875 \& \mathrm{t}=$ downloads

KOFES, M. S. Colcha de retalhos: estudos sobre a família no Brasil. São Paulo, Brasiliense, 1982. 
LETICHE, H. Doubling: there's an escape from commodification ...? Society and Business Review 4(1), 2009, pp.8-25. DOI: 10.1108/17465680910932432

LUXEMBURG, R. Womens Suffrage and Class Struggle. Selected Political Writings, New York, 1971.

MAINGUENEAU, D. Termos-chave da análise do discurso. Belo Horizonte, Editora UFMG, 2006.

MILES, R.; TORRES, R. Does 'race' matter: Transatlantic perspectives on racism and 'race relations'. In: GUPTA, T.D.; JAMES C.E.; MAAKA R.C.A.; GALABUZI G.E.; ANDERSEN C. (ed.). Race and Racialization: Essential Readings. Toronto, Canadian Scholars' Press, 2007, pp.65-73.

OLIVEIRA, E. P. Cursos para trabalhadoras domésticas. estratégias de modelagem. Master's dissertation, Universidade Estadual de Campinas, 2007.

PEREIRA, M. C.; BRITO, M. J. A análise do discurso como prática e processo de produção de sentidos: proposta teóricometodológica. In: CARRIERI, A. P.; SARAIVA, L. A. S.; PIMENTEL, T. D.; SOUZA-RICARDO, P. A. (org.). Análise do discurso em estudos organizacionais. Curitiba, Juruá, 2009, pp.53-78.

PRASAD, A. Beyond analytical dichotomies. Human Relations 65(5), 2012, pp.567-595. DOI: 10.1177/0018726711432183

PREUSS, M. R. G. Patroas e empregadas: relações de proximidade e oposição. Coletâneas da ANPEPP 2(1), 1996, pp.53-65. Retrieved January 28, 2016, from https://www.anpepp.org.br/acervo/Colets/v01n07a006.pdf

RANGEL, H. M. V. A. A discriminação sócio jurídica ao emprego doméstico na sociedade brasileira contemporânea: uma projeção do passado colonial. Jus Navigandi 23(1), 2010, pp.33-57. Retrieved January 28, 2016, from https://jus.com.br/artigos/14215/a-discriminacao-sociojuridica- 
a-empregada-domestica-na-sociedade-brasileiracontemporanea

RONCADOR, S. Histórias paranoicas, criados perversos no imaginário literário da Belle Époque tropical. Estudos de Literatura Brasileira Contemporânea (29), 2007, pp.127-140. Retrieved January 28, 2016, from https://periodicos.unb.br/index.php/estudos/article/view/9122

RONCADOR, S. Criadas no more: notas sobre testemunho de empregadas domésticas. Estudos de Literatura Brasileira Contemporânea (21), 2003, pp.55-71. Retrieved January 28, 2016, from https://periodicos.unb.br/index.php/estudos/article/view/8929

RUBIN, G. O trafico de mulheres. notas sobre a "economia política" do sexo. (1993) POR FAVOR, INFORME EDITORA E LOCAL DE EDIÇÃO

SARAIVA, L. A. S. Mercantilização da cultura e dinâmica simbólica local: a indústria cultural em Itabira, Minas Gerais. Doctoral dissertation, Universidade Federal de Minas Gerais, 2009.

SILVA, A. P. da; BLANCHETTE, T. G. Por amor, por dinheiro? Trabalho (re) produtivo, trabalho sexual e a transformação da mão-de-obra feminina. cadernos pagu, (50), Campinas-SP, Núcleo de Estudos de Gênero-Pagu, 2018. DOI: 10.1590/18094449201700500019.

SILVA, E. B. Tecnologia e vida doméstica nos lares. cadernos pagu (10), Campinas-SP, Núcleo de Estudos de Gênero-Pagu, 1998, pp.21-52. Retrieved January 28, 2016, from https://periodicos.sbu.unicamp.br/ojs/index.php/cadpagu/article/ view/2135/2255

SILVA, L. R. M.; OLIVEN, L. R. A. O "doméstico" do doméstico parte 2: o caso Mangueira. In: Encontro Nacional do Conpedi, 19., 2010, Fortaleza. Anais... Fortaleza: CONPENDI, 2010. Retrieved January 28, 2016, from 
http://www.publicadireito.com.br/conpedi/manaus/arquivos/ana is/fortaleza/3022.pdf

SILVA, M. D. F. da.; OLIVEIRA, J. S. de; GOUVÊA, J. B.; SOUZA, V. G. de. Contribuições do conceito de branquitude às pesquisas sobre raça nos estudos organizacionais. In: Encontro da ANPAD, 44., 2020, on-line. Anais... Rio de Janeiro: ANPAD, 2020. Retrieved November 13, 2020, from http://anpad.org.br/eventos.php?cod_evento $=1 \&$ cod_evento_e dicao $=106 \&$ cod_edicao_subsecao $=1726 \&$ cod_edicao_trabalh $\mathrm{o}=29152$

SANTOS, N. D. S. Tornar-se negro: as vicissitudes da identidade do negro brasileiro em ascensão social. Rio de Janeiro: Edições Graal, 1983.

STEIL, A. V. Organizações, gênero e posição hierárquicacompreendendo o fenômeno do teto de vidro. Revista de Administração da Universidade de São Paulo 32(3), 1997. Retrieved January 28, 2016, from https://www.researchgate.net/publication/237050206_Organiza coes_genero_e_posicao_hierarquica__compreendendo_o_fenomeno_do_teto_de_vidro

VAN DIJK, T. A. Discourse as interaction in society. In: VAN DIJK, T. A. (ed.). Discourse as social interaction. London, Sage, 1997, pp.1-37.

VIANNA, C. P. O sexo e o gênero da docência. cadernos pagu, (17-18), Campinas-SP, Núcleo de Estudos de Gênero-Pagu, 2001, pp.81-103. Retrieved January 28, 2016, from https:/www.scielo.br/pdf/cpa/n17-18/n17a03.pdf

VÍTIMAS de empregada doméstica. Comunidade Orkut, June 2012. Retrieved July, 7, 2012, from http://orkut.google.com/c686748.html

WAGNER, A.; PREDEBON, J.; MOSMANN, C.; VERZA, F. Compartilhar tarefas? Papeis e funções de pai e mãe na família 
contemporânea. Psicologia-Teoria e Pesquisa, 21(2), 2005, pp.181-186. DOI: 10.1590/S0102-37722005000200008.

WONG, L. Postcolonial interventions and disruptions: contesting cultural practices. International Journal of Cross Cultural Management 10(3), 2010, pp.345-362. DOI: $10.1177 / 1470595810389795$ 